Research article

Open Access

\title{
The expression of the ubiquitin ligase subunit Cks1 in human breast cancer
}

\author{
Merav Slotky ${ }^{1}$, Ma'anit Shapira ${ }^{1}$, Ofer Ben-lzhak², Shai Linn ${ }^{4}$, Boris Futerman ${ }^{4}$, Medy Tsalic ${ }^{3}$ and \\ Dan D Hershko ${ }^{1,5}$
}

\begin{abstract}
1Department of Surgery A, Rambam Medical Center and the Technion-Israel Institute of Technology, Haifa, Israel 2Department of Pathology, Rambam Medical Center and the Technion-Israel Institute of Technology, Haifa, Israel ${ }^{3}$ Department of Medical Oncology, Rambam Medical Center and the Technion-Israel Institute of Technology, Haifa, Israel 4 Unit of Clinical Epidemiology, Rambam Medical Center and the Technion-Israel Institute of Technology, Haifa, Israel ${ }^{5}$ Breast Health Institute, Rambam Medical Center and the Technion-Israel Institute of Technology, Haifa, Israel

Corresponding author: Dan D Hershko,d_hershko@rambam.health.gov.il
\end{abstract}

Received: 4 Apr 2005 Revisions requested: 4 May 2005 Accepted: 31 May 2005 Published: 19 Jul 2005

Breast Cancer Research 2005, 7:R737-R744 (DOI 10.1186/bcr1278)

This article is online at: http://breast-cancer-research.com/content/7/5/R737

(c) 2005 Slotky et al.; licensee BioMed Central Ltd.

This is an Open Access article distributed under the terms of the Creative Commons Attribution License (http://creativecommons.org/licenses/by/ 2.0), which permits unrestricted use, distribution, and reproduction in any medium, provided the original work is properly cited.

\begin{abstract}
Introduction Loss of the cell-cycle inhibitory protein p27Kip1 is associated with a poor prognosis in breast cancer. The decrease in the levels of this protein is the result of increased proteasome-dependent degradation, mediated and rate-limited by its specific ubiquitin ligase subunits S-phase kinase protein 2 (Skp2) and cyclin-dependent kinase subunit 1 (Cks1). Skp2 was recently found to be overexpressed in breast cancers, but the role of Cks1 in these cancers is unknown. The present study was undertaken to examine the role of $\mathrm{Cks} 1$ expression in breast cancer and its relation to $\mathrm{p} 27^{\mathrm{Kip} 1}$ and Skp2 expression and to tumor aggressiveness.
\end{abstract}

Methods The expressions of Cks1, Skp2, and p27Kip1 were examined immunohistochemically on formalin-fixed, paraffinwax-embedded tissue sections from 50 patients with breast cancer and by immunoblot analysis on breast cancer cell lines. The relation between Cks1 levels and patients' clinical and histological parameters were examined by Cox regression and the Kaplan-Meier method.

Results The expression of Cks1 was strongly associated with Skp2 expression $(r=0.477 ; P=0.001)$ and inversely with p27Kip1 $(r=-0.726 ; P<0.0001)$. Overexpression of Cks1 was associated with loss of tumor differentiation, young age, lack of expression of estrogen receptors and of progesterone receptors, and decreased disease-free $(P=0.0007)$ and overall $(P=0.041)$ survival. In addition, Cks1 and Skp2 expression were increased by estradiol in estrogen-dependent cell lines but were down-regulated by tamoxifen.

Conclusion These results suggest that Cks1 is involved in p27 Kip1 down-regulation and may have an important role in the development of aggressive tumor behavior in breast cancer.

\section{Introduction}

The prognosis and clinical management of patients with breast cancer are commonly determined by traditional clinicopathological factors such as tumor size and grade, lymph node status, and the expression of receptors to estrogen (ERs) and to progesterone (PRs) and of Her2/neu [1]. Nevertheless, patients may have significantly different clinical outcomes despite similar clinicopathological features. Some of these differences may be attributed to alterations in the normal regulation of the cell cycle that ultimately lead to aggressive tumor behavior.
Among the various cell-cycle proteins, deregulation of p27Kip1 expression was found to have a particularly important role in cancer [2]. Numerous studies have shown that down regulation of p27Kip1, an inhibitor of cyclin-dependent kinases, is associated with poor prognosis in many cancers, including breast, colorectal, prostate, and lung carcinomas [3-8]. The decrease in $\mathrm{p} 27^{\mathrm{Kip} 1}$ levels in these cancers was found to result from its rapid degradation by the ubiquitin-proteasome pathway, rather than from decreased protein synthesis or gene mutation $[6,9,10]$. 
The main rate-limiting regulator for $\mathrm{p} 27^{\mathrm{Kip} 1}$ degradation was identified as an SCF-type ubiquitin ligase complex that contains S-phase kinase protein 2 (Skp2) as the specific substrate-recognition subunit [11-13]. Skp2 specifically binds $\mathrm{p} 27^{\mathrm{Kip} 1}$ and targets it for degradation by the ubiquitin proteolytic system. The important role of Skp2 in controlling p27Kip1 levels in some human cancers, including breast, prostate, colorectal, and oral squamous cell carcinomas, was recently emphasized [14-17]. Thus, increased expression of Skp2 in these tumors was associated with low p27Kip1 levels, aggressive tumor behavior, and poor overall survival.

More recently, the essential role of cyclin kinase subunit 1 (Cks1) in facilitating the ubiquitin-mediated proteolysis of $\mathrm{p} 27^{\mathrm{Kip} 1}$ through interaction with Skp2 was discovered $[18,19]$. Cks 1 is a member of the highly conserved family of Cks/Suc1 (Schizosaccharomyces pombe cell-cycle regulatory protein) proteins, which interact with Cdks (cyclin-dependent kinase), but its exact mechanism of action remained poorly understood until recently. Cks1 was found to be an essential cofactor for efficient Skp2-dependent ubiquitination of p27Kip1. The critical role of $\mathrm{Cks} 1$ in targeting $\mathrm{p} 27^{\mathrm{Kip} 1}$ for efficient degradation by Skp2 was emphasized by demonstrating the lack of p27Kip1 ubiquitination and breakdown in the absence of Cks1 in vitro and the slow proliferation and accumulation of p27Kip1 in Cks1 nullizyous mice in vivo $[18,19]$. Recent studies from our and other laboratories have investigated the expression of Cks1 levels in different human cancers and its relation to Skp2 and p27Kip1 expression [20-24]. For example, we have shown that in colorectal cancer the expression of Cks1 protein levels correlated strongly with the expression of Skp2 protein levels and inversely with those of p27Kip1 [23]. Furthermore, Cks1 expression was increased in poorly differentiated tumors and was strongly and independently associated with poor overall survival [24]. The role of Cks1 in breast cancer, however, is unknown.

In the present study, we investigated the expression of Cks1 in relation to Skp2 and $\mathrm{p} 27^{\mathrm{Kip} 1}$ and prognosis in breast cancer. We show that Cks1 expression is strongly associated with Skp2 expression and inversely associated with p27Kip1 expression. Furthermore, our results suggest that Cks1 expression may be used as an independent prognostic marker for disease-free and overall survival in breast cancer.

\section{Materials and methods Patients and tissue samples}

Tissue samples from 50 patients with primary breast carcinomas that had been operated on more than 6 years before the beginning of the study were collected for immunohistochemical studies, after we had obtained the approval of the institution's Human Investigation Committee. Patients presenting with metastatic disease were excluded from this study. Clinical and histological data were available for all of these patients.
Long-term follow-up data were provided by patients' medical records and the Israel Cancer Registry.

\section{Cell cultures}

Human breast cancer cell lines (MCF-7, T47D, and MDA-MB231) were generously provided by Dr H Degani (Weizmann Institute of Science, Rehovot, Israel). Because Skp2 levels change during the cell cycle (being normally highest in the $S$ phase and lowest in the G1 phase) we cultured the cells in different media under conditions of similar proliferation rate in all cell lines. MDA-MB-231 cells were grown in RPMI medium (Biological Industries, Beth Ha'emek, Israel) supplemented with $10 \%$ fetal calf serum, 100 Units penicillin, and $100 \mu \mathrm{g}$ streptomycin per $\mathrm{ml}$ and $1 \mathrm{mM}$ sodium pyruvate. MCF-7 breast carcinoma cells were cultured in Dulbecco's modified Eagle's medium (DMEM; Biological Industries) supplemented with $10 \%$ fetal bovine serum, $4.5 \mathrm{~g} / \mathrm{l}$ glucose, antibiotics as described above, and $4 \mathrm{mM}$ glutamine. The T47D cell line was cultured in RPMI medium supplemented with 10\% fetal calf serum, 100 Units $/ \mathrm{ml}$ penicillin, $100 \mu \mathrm{g} / \mathrm{ml}$ streptomycin, and $10 \mu \mathrm{g} / \mathrm{ml}$ insulin. All cell lines were cultured at $37^{\circ} \mathrm{C}$ in $5 \%$ $\mathrm{CO}_{2}$. Under these conditions, the proliferation rate of all cell lines was similar (21 to 22 hours doubling time).

\section{Immunoblotting}

Samples containing $30 \mu \mathrm{g}$ of protein were resolved by electrophoresis on a $12.5 \%$ SDS-polyacrylamide gel and were transferred to nitrocellulose membranes. The membranes were probed with affinity-purified rabbit polyclonal antibody directed against a 12-amino-acid synthetic peptide from the extreme $\mathrm{C}$ terminus of human Cks1 (gift of Dr A Hershko, Technion, Haifa, Israel). This antibody does not cross-react with Cks2. The antibody was diluted 1:200 in TBST (Tris-buffered saline and $0.1 \%$ Tween 20 ) containing $10 \%(\mathrm{w} / \mathrm{v})$ nonfat dry milk. Membranes were also probed against the mouse monoclonal antibody directed against Skp2 (Zymed Laboratories Inc, South San Francisco, CA, USA) diluted 1:500, or with a rabbit polyclonal antibody directed against p27Kip1 (Zymed) diluted at 1:250. Membranes were also probed with a mouse monoclonal antibody directed against Skp1 (Transduction Laboratories, Lexington, KY, USA; 1:1000 dilution). Since levels of Skp1 do not change in the cell cycle, this protein served as an internal control to normalize for loading of cellular protein. After being washed with TBST, the immunoreactive proteins were visualized with horseradish-conjugated lgG (Pierce, Rockford, IL, USA) diluted 1:10,000 and an enhanced chemiluminescence system (SuperSignal West Pico; Pierce). All immunoblot analyses were done at least twice.

\section{Immunohistochemistry}

Immunohistochemical studies were performed on formalinfixed tissue sections embedded in paraffin wax. Five-micron sections were deparaffinized with xylene and rehydrated in a series of ethanols. 
For epitope retrieval, slides were heated in $1 \mathrm{mM}$ ethylenediaminetetraacetic acid buffer ( $\mathrm{pH} 8$ ), either in a microwave oven at $92^{\circ} \mathrm{C}$ for $20 \mathrm{~min}$ (p27 Kip 1 ) or in an Antigen Retrieval Processor (Milestone Inc, Sorsiole, Italy) at $120^{\circ} \mathrm{C}$ for $8 \mathrm{~min}$ (Skp2 and $\mathrm{Cks} 1$ ). After they had cooled, the slides were washed in distilled water.

Skp2 staining was carried out in the NexES IHC Immunostainer (Ventana Medical Systems, Tucson, AZ, USA), in accordance with the manufacturer's instructions, using a monoclonal antibody (Zymed) diluted 1:100.

Slides for $\mathrm{p} 27^{\mathrm{Kip} 1}$ and $\mathrm{Cks} 1$ staining were treated for $10 \mathrm{~min}$ with $3 \% \mathrm{H}_{2} \mathrm{O}_{2}$ in methanol to block endogenous peroxidase and for 30 min with $10 \%$ nonimmune rabbit serum to block nonspecific protein binding. The slides were then washed in water and soaked in washing buffer ( $\mathrm{pH} 7.4$, Optimax; Biogenex, San Ramon, CA, USA) for $5 \mathrm{~min}$. For p27Kip1 staining, slides were incubated overnight at $4^{\circ} \mathrm{C}$ with the monoclonal p27Kip1 antibody diluted 1:500. Staining was completed with a Histostain-plus kit (Zymed) in accordance with the manufacturer's instructions. For Cks1 staining, slides were incubated with an affinity-purified rabbit polyclonal antibody directed against a 12-amino-acid synthetic peptide from the extreme C terminus of human Cks1 (described above) diluted 1:40 for 2 hours at room temperature. Staining was completed using a Super-sensitive Multilink Immunodetection kit (Biogenex) in accordance with the manufacturer's instructions. The color reaction product was developed with aminoethyl carbazole (AEC). All sections were counterstained with hematoxylin.

For negative controls, slide sections that were positive for staining were treated with $10 \%$ nonimmune rabbit serum (Zymed) instead of the primary antibody. No staining was observed in any of these controls.

The immunohistochemical slides were scored according to the percentage of tumor cells exhibiting nuclear staining. To define high and low protein expression, we used a cutoff of $50 \%$ p 27 Kip1 and 10\% for Skp2, which is the cutoff used in most previous studies $[14,15]$. The cutoff for Cks1 was $10 \%$, similar to the level used for Skp2, as in previous studies. When stained, cells displayed similar intensities of nuclear staining regardless of the percentage of cells stained, and therefore the intensity of staining was not included in the score. The specificity of immunohistochemistry staining procedures for Skp2, Cks1, and p27Kip1 was previously verified by comparing the protein levels as determined by immunohistochemistry with the protein levels determined by immunoblot analysis from the same tumor specimens $[15,23]$.

\section{Statistical analysis}

Statistical data analyses were performed using SPSS 11.0 statistical software package (SPSS Inc, Chicago, IL, USA). First, the relations between Skp2, Cks1, and p27Kip1 and those between protein levels and various clinical and pathological features were studied using cross tabulation and Pearson's $\chi^{2}$. Survival curves were constructed using the KaplanMeier method and multivariate analysis by Cox regression; $P$ values less than 0.05 were considered significant.

\section{Results \\ Cks1 protein expression is directly related to Skp2 expression and inversely related to p27 Kip1 expression in human breast cancer}

We studied the expression of Cks1, Skp2, and p27Kip1 by immunohistochemistry in 50 tumor samples obtained from patients with breast cancer. The quality of immunostaining was good, with minimal background reactivity. Cks1 levels were very low or absent in all normal breast tissues adjacent to tumors. However, Cks1 levels were not uniformly high in all tumor specimens, being very high in some but virtually absent in others (Table 1). Given the important biochemical link between Cks1, Skp2, and p27Kip1, we examined the correlation between these proteins. Regression analysis of all 50 cases showed an inverse correlation between Skp2 and p27Kip1 levels ( $r=-0.395 ; P=0.005)$. Cks1 expression was strongly related to Skp2 expression $(r=0.477 ; P=0.001)$ and inversely related to $\mathrm{p} 27^{\mathrm{Kip} 1}$ levels $(r=-0.726 ; P<0.001)$. Thus, strong relations were found between the expressions of all three proteins in 74\% of the patients. High levels of Cks1 and Skp2 with low levels of p27Kip1 were observed in 15 patients, and low levels of Cks1 and Skp2 with high levels of p27Kip1 were observed in 22 patients. A typical representative immunohistochemical sample is shown in Fig. 1. In this tumor sample, cancer cells show strong nuclear staining for Cks1 and Skp2 and weak staining for p27Kip1, but high p27Kip1 staining and low Cks1 and Skp2 staining in the normal surrounding breast tissue. In 13 of the 50 cases, the above relation was not found. In eight cases an inverse relation was found between Cks1 and p27Kip1 expression but not between Skp2 and p27Kip1 expression; in three cases, levels of both p27Kip1 and Skp2 were high whereas Cks1 expression was low; and in another five cases, p27Kip1 levels were low despite high Cks1 levels and low Skp2 levels. In another five cases, the differences between the three proteins were not significant.

\section{Cks1 overexpression is associated with poor tumor differentiation, young age, and negative ER/PR status}

To examine the relation between Cks1 expression and common parameters associated with aggressive tumor behavior, we compared Cks1 levels with various clinicopathological features such as age, tumor size, pathological grade, lymph node status, and ER and PR expression (Table 1). A significant direct correlation was found between high Cks1 levels and loss of tumor differentiation $(r=-0.421 ; P=0.012)$, negative ER expression $(r=-0.356 ; P=0.013)$, and negative $P R$ expression $(r=-0.404 ; P=0.006)$. We also found a strong relation between $\mathrm{Cks} 1$ overexpression and patient age less than than 50 years $(r=0.327 ; P=0.049)$, but did not observe 
Table 1

Relations between protein ${ }^{a}$ expression and clinicopathological characteristics in patients with breast cancer

\begin{tabular}{|c|c|c|c|c|c|c|c|c|c|}
\hline \multirow[t]{2}{*}{ Characteristic } & \multicolumn{3}{|c|}{ Cks1 } & \multicolumn{3}{|c|}{ Skp2 } & \multicolumn{3}{|c|}{ p27 Kip1 } \\
\hline & High & Low & $P^{\mathrm{b}}$ & High & Low & $P^{b}$ & High & Low & $P b$ \\
\hline \multicolumn{10}{|l|}{ Grade } \\
\hline 1 & 2 & 8 & 0.012 & 2 & 8 & 0.005 & 2 & 8 & 0.032 \\
\hline 2 & 14 & 14 & 0.012 & 7 & 21 & 0.005 & 14 & 14 & 0.032 \\
\hline 3 & 10 & 2 & 0.012 & 9 & 3 & 0.005 & 8 & 4 & 0.032 \\
\hline \multicolumn{10}{|l|}{ Tumor size ${ }^{c}$} \\
\hline $\mathrm{T} 1$ & 15 & 18 & 0.333 & 10 & 23 & 0.265 & 19 & 14 & 0.485 \\
\hline T2 & 10 & 6 & 0.333 & 7 & 9 & 0.265 & 8 & 8 & 0.485 \\
\hline Тз & 1 & 0 & 0.333 & 1 & 0 & 0.265 & 0 & 1 & 0.485 \\
\hline \multicolumn{10}{|c|}{ Lymph node involvement ${ }^{c}$} \\
\hline No & 16 & 15 & 0.508 & 11 & 20 & 0.803 & 18 & 13 & 0.387 \\
\hline $\mathrm{N} 1$ & 6 & 3 & 0.508 & 4 & 5 & 0.803 & 3 & 6 & 0.387 \\
\hline N2 & 4 & 6 & 0.508 & 3 & 7 & 0.803 & 6 & 4 & 0.387 \\
\hline \multicolumn{10}{|c|}{ Estrogen receptor expression } \\
\hline Negative & 17 & 6 & 0.013 & 16 & 7 & 0.001 & 9 & 14 & 0.048 \\
\hline Positive & 10 & 17 & 0.013 & 3 & 24 & 0.001 & 17 & 10 & 0.048 \\
\hline \multicolumn{10}{|c|}{ Progesterone receptor expression } \\
\hline Negative & 15 & 3 & 0.006 & 14 & 4 & 0.001 & 5 & 13 & 0.032 \\
\hline Positive & 12 & 20 & 0.006 & 4 & 27 & 0.001 & 20 & 12 & 0.032 \\
\hline \multicolumn{10}{|l|}{ Age (years) } \\
\hline$>50$ & 14 & 5 & 0.017 & 12 & 7 & 0.002 & 7 & 12 & 0.051 \\
\hline$<50$ & 12 & 19 & 0.017 & 25 & 6 & 0.002 & 20 & 11 & 0.051 \\
\hline
\end{tabular}

aCks1, cyclin kinase subunit 1; p27Kip1, a cell-cycle inhibitory protein; Skp2, S-phase kinase protein 2. bRefers to the differences between protein expression and the variables. 'According to the TNM (tumor, node, metastases) staging system of the American Joint Committee on Cancer. $P \leq$ 0.05 (values shown in bold type) was considered statistically significant.

a significant correlation between Cks1 levels and lymph node status $(r=0.029 ; P=0.508)$ or tumor size $(r=0.192 ; P=$ 0.333).

Examination of the association between Skp2 or p27Kip1 and patients' clinicopathological characteristics showed a strong association between Skp2 expression and loss of tumor differentiation $(r=-0.400 ; P=0.005)$, young age $(r=-0.337 ; P=$ $0.022)$, and negative ER or negative PR status ( $r=-0.589 ; P$ $=0.001$ and $r=-0.674 ; P=0.001)$, respectively. Loss of p27Kip1 was associated with loss of tumor differentiation $(r=$ 0.323; $P=0.032)$ and, respectively, loss of ER and PR $(r=$ $0.298, P=0.048 ; r=-0.316, P=0.030$ (Table 1$)$ ).

Because of the strong association between Cks1, Skp2, and p2 $7^{\mathrm{Kip} 1}$ levels and the ER status of the tumors, we next examined the expression of these proteins in estrogen-dependent (MCF-7 and T47D) and estrogen-independent (MDA-MB231) breast carcinoma cell lines, and the possible effects of estrogen modulation on the regulation of Skp2 and Cks1 expression. Basal levels of Cks1 and Skp2 were higher in estrogen-independent cells than in estrogen-dependent cells, whereas p27Kip1 levels were lower (Fig. 2a). Interestingly, between the two estrogen-dependent cell lines, levels of Cks 1 and Skp2 were higher in T47D cells, which phenotypically have poorer cellular differentiation (Fig. 2b). Treatment of T47D cells with estradiol increased Cks1 and Skp2 levels, whereas treatment with tamoxifen down regulated Cks1 and Skp2, resulting in an upregulation of p27Kip1 levels (Fig. 2b).

\section{Cks1 overexpression is associated with poor disease- free and overall survival in human breast cancer}

To determine the association between Cks1 expression and prognosis, we plotted Kaplan-Meier curves for disease-free survival and overall survival. Complete 80-month follow-up data were available for all the patients. Patients presenting with high tumor Cks1 levels had significantly shorter diseasefree survival rates than patients with low Cks1 levels (54 
Figure 1
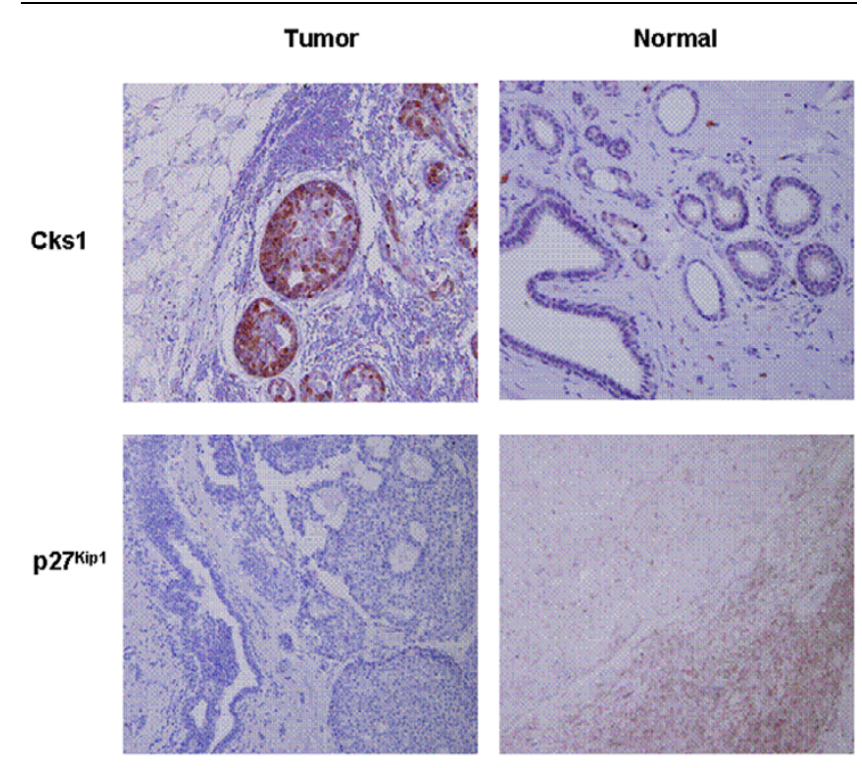

Skp2
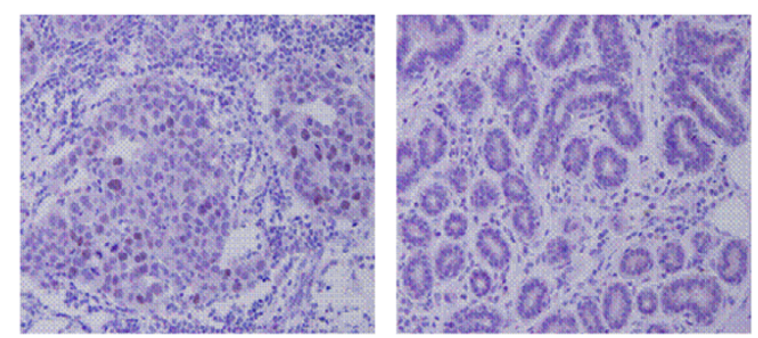

Representative immunohistochemistry slides for Cks1, Skp2, and p27 Kip1 staining in breast cancer. Tumor cells of a grade II invasive duct cancer exhibiting strong and diffuse nuclear staining for Skp2 (S-phase kinase protein 2) and Cks1 (cyclin kinase subunit 1) $(\times 300)$ and low p27 Kip1 staining. Note the inversely low Skp2 and Cks1 staining with high $\mathrm{p} 27^{\mathrm{Kip} 1}$ staining of normal adjacent breast tissue $(\times 400)$.

months vs 76 months, respectively; $P=0.0007$; Fig. 3a). There was only one case of disease recurrence in patients with low Cks1 levels, whereas in patients with high Cks1 levels, disease recurrence was observed in 11 (42\% of patients). Similarly, Skp2 and p27Kip1 were also good predictors for disease-free survival $(P=0.0014$ and $P=0.0191$, respectively; data not shown).

We also examined the prognostic role of $\mathrm{Cks} 1$ in predicting local or distant relapse disease-free survival (Fig. 3b,c, respectively). Patients with high Cks1 levels had both higher local recurrence rates $(P=0.0352)$ and more distant relapse rates $(P=0.0006)$ than patients with low $C k s 1$ levels. Skp2 was also found to be a good predictor for local $(P=0.0051)$ and distal $(P=0.003)$ relapse rates, while $\mathrm{p} 27^{\mathrm{Kip} 1}$ expression was a predictor for distant relapse $(P=0.031)$ but not for local recurrence $(P=0.136)$.

There was also a strong association between Cks1 expression and overall survival (Fig. 4a). The mean survival rate for
Figure 2

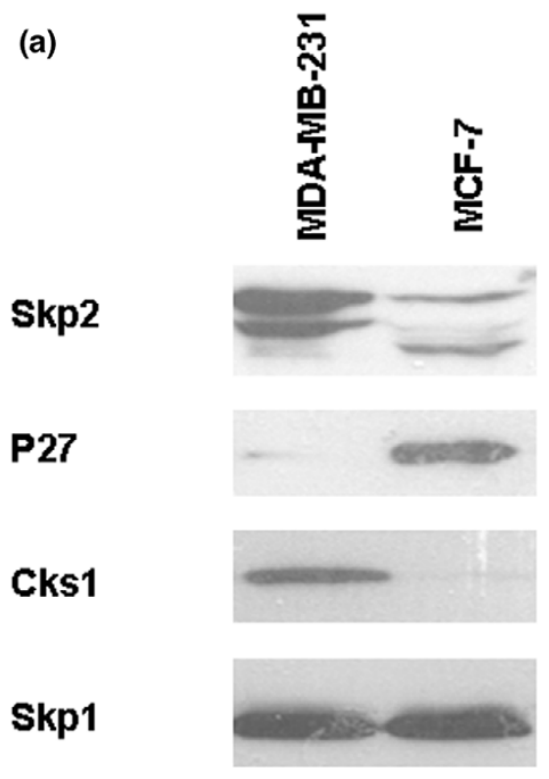

(b)

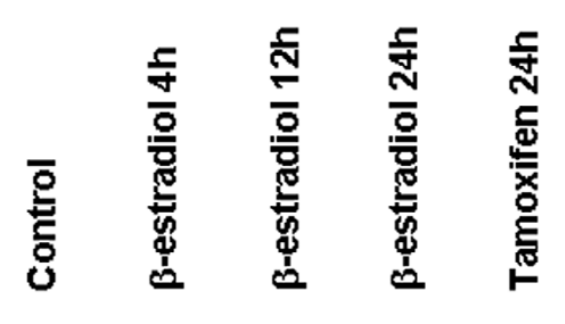

Skp2

P27

Cks1

\section{Skp1}

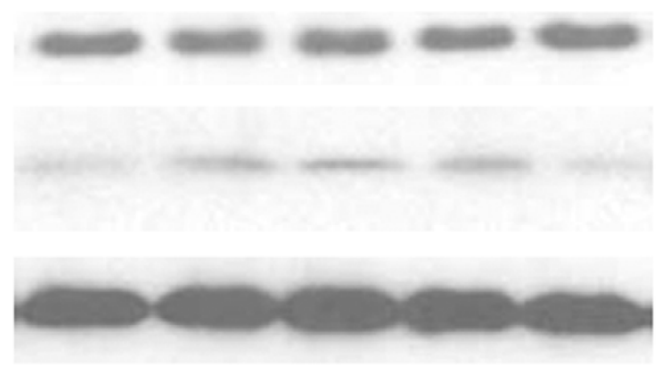

Immunoblots showing Cks1, Skp2, and p27Kip1 proteins in breast cancer cell lines. (a) Levels of the three proteins Cks1 (cyclin kinase subunit 1), Skp2 (S-phase kinase protein 2), and p27Kip1 were measured in MDA-MB-231 (an estrogen-independent cell line) and MCF-7 (an estrogen-dependent cell line). Skp1 levels were determined to confirm equal protein loading. (b) Effect of estrogen modulation on Cks1, Skp2, and p27Kip1 expression in T47D cells (an estrogen-dependent breast cancer cell line) treated with estradiol $(0.5 \mu \mathrm{M})$ or tamoxifen $(10 \mu \mathrm{M})$. P27, p27 Kip1. 
Figure 3
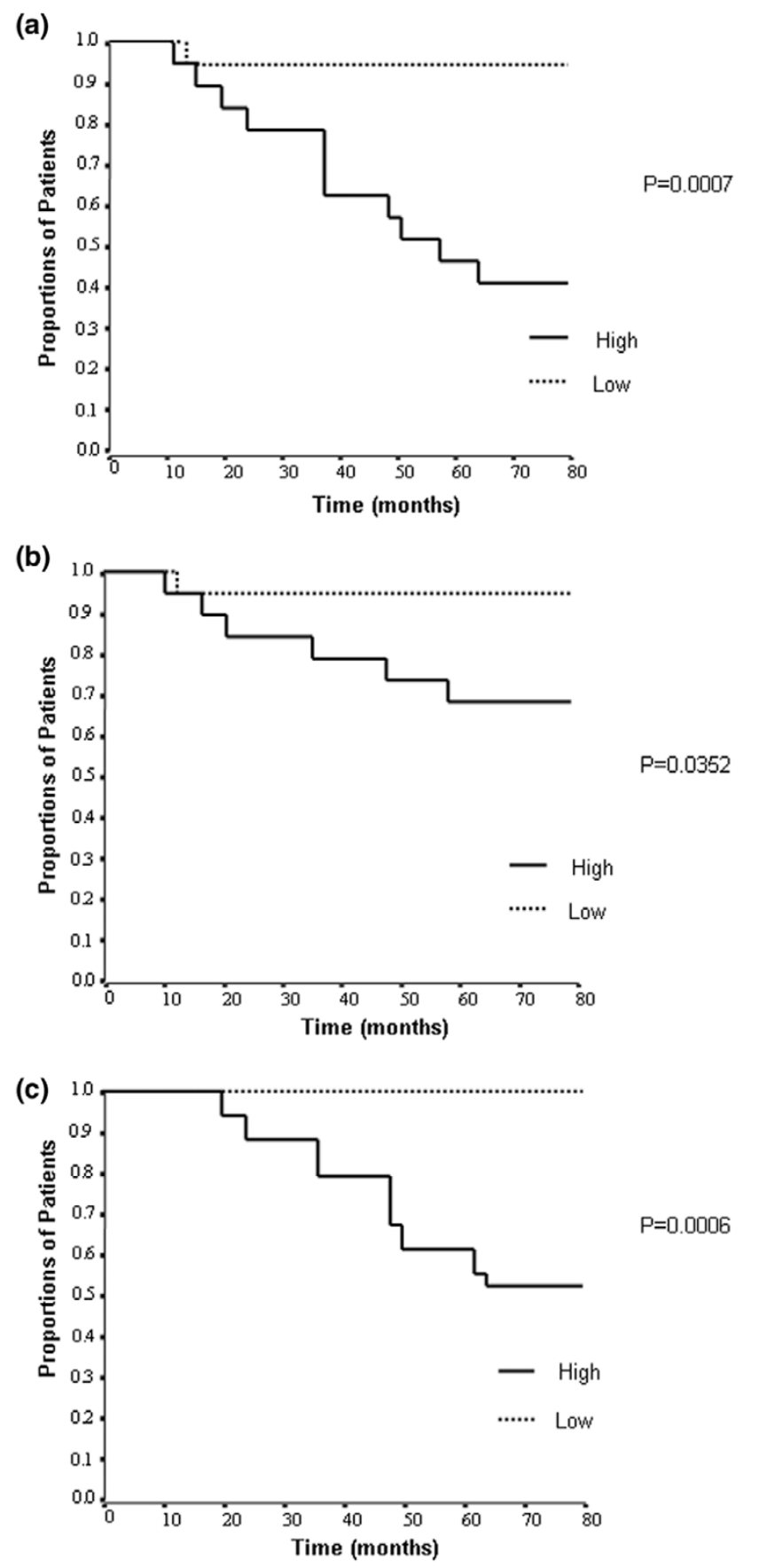

The association between Cks 1 expression and disease-free survival. The expression of Cks1 (cyclin kinase subunit 1) was plotted in relation to overall (a), local (b), or distant (c) recurrence rates. Analyses were constructed using the Kaplan-Meier method. Protein expression was considered low if fewer than $10 \%$ of cell nuclei were stained and high if more than $10 \%$ of nuclei were stained.

patients with low Cks1 expression was 79 months, significantly higher than that (72 months) of patients with high Cks 1 levels $(P=0.0415)$. Similarly, Skp2 expression was also found to be a strong predictor of overall survival (69 months vs 79
Figure 4

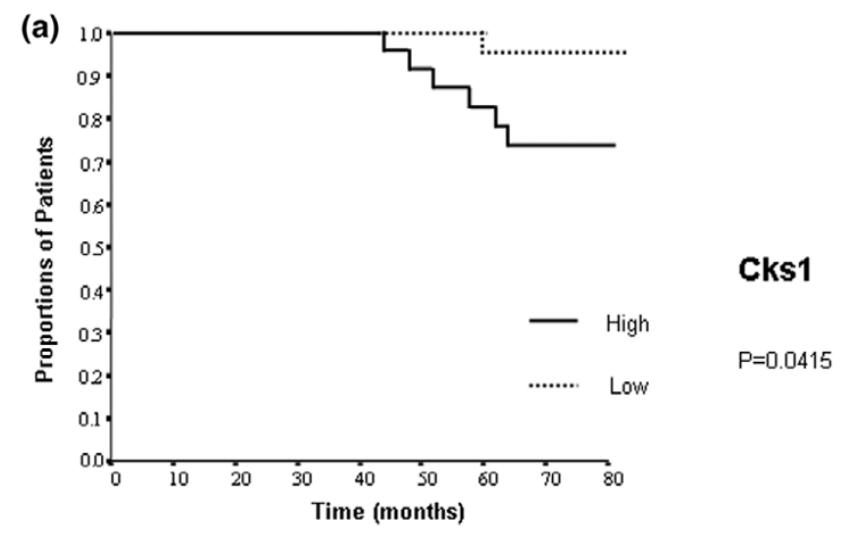

(b)

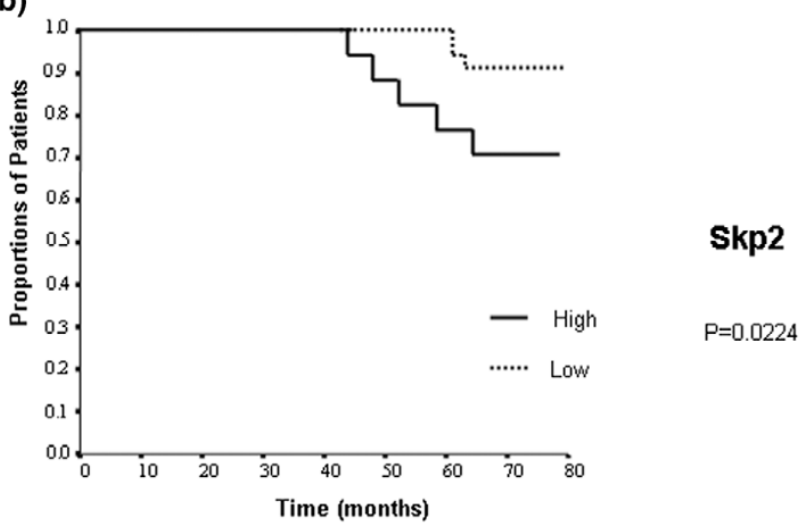

(c)

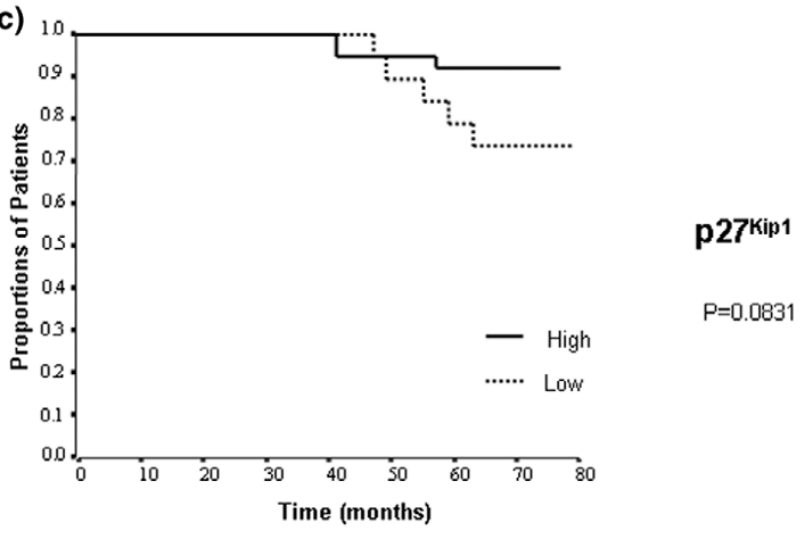

The association between expression of cell cycle proteins and survival of patients with breast cancer. Relation between Cks1 (cyclin kinase subunit 1)(a), Skp2 (S-phase kinase protein 2) (b), and p27Kip1 (c) expression and overall survival (death). Analyses were constructed using the Kaplan-Meier method. Protein expression was considered low if fewer than $10 \%$ of cell nuclei were stained and high if more than $10 \%$ of nuclei were stained.

months $P=0.0224$ ) (Fig. 4b), but $\mathrm{p} 27^{\mathrm{Kip} 1}$ expression was not $(P=0.0831 ;$ Fig. $4 \mathrm{c})$.

\section{Discussion}

Recent studies have clearly shown that Cks1 plays an essential role in Skp2-mediated degradation of p27Kip1. The mecha- 
nistic model that emerges from these studies suggests that Cks1 is associated with Skp2 and confers an allosteric change in Skp2 that increases its affinity for phosphorylated p27Kip1 [18]. As a result, the Cks1-Skp2 interaction enables efficient transfer of ubiquitin to $\mathrm{p} 27^{\mathrm{Kip} 1}$, resulting in rapid proteasome-mediated degradation. Whereas the role of Skp2 as an oncogene responsible for down regulation of $\mathrm{p} 27^{\mathrm{Kip} 1}$ protein levels has been well established in a wide variety of cancers, the role of Cks1 in many of these cancers, and in particular breast cancer, is unknown. This study provides new insights into its role in human breast cancer. Using immunohistochemical studies obtained from tumor specimens of patients with nonmetastatic breast cancer, we found that Cks1 was overexpressed in subsets of patients with unfavorable histological features. Furthermore, its expression was strongly and independently associated with poor disease-free survival and poor overall survival. Similar findings were recently reported by our and other laboratories in aggressive gastric, lung, oral, and colorectal carcinomas [20-24]. Taken together, these results suggest that Cks 1 has an important role in the decrease in p2 $7^{\text {Kip } 1}$ levels in aggressive cancers.

The interaction between the three proteins was evident in a significant proportion of the study patients, whereby the expression of Cks1 was strongly associated with Skp2 expression and inversely with $\mathrm{p} 27^{\mathrm{Kip} 1}$ protein levels. However, in five patients high Cks1 levels were associated with low p27Kip1 despite low Skp2 levels, and in three patients Cks1 levels were high but Skp2 and p27Kip1 levels were low. These findings, in which the inverse relation between Cks1 and p27Kip1 was stronger than that between Skp2 and p27Kip1 levels, are particularly interesting, considering that Skp2 is the prime mediator of $p 27^{K i p 1}$ degradation. Although we do not yet know the reason for this observation, we postulate that in the presence of high Cks1 levels Skp2 degradation of p27Kip1 is more efficient and that lower levels of Skp2 are therefore required to down-regulate $\mathrm{p} 27^{\mathrm{Kip} 1}$.

Cks1 overexpression was also strongly associated with various clinical and pathological features that are commonly used to determine aggressive tumor behavior, including poor tumor differentiation and lack of receptors to estrogen and progesterone. The association between Cks1, Skp2, and p2 $7^{\mathrm{Kip} 1}$ and ER expression was also observed in breast carcinoma cell lines. Estrogen-dependent cell lines displayed lower levels of Cks1 and Skp2 than estrogen-independent cell lines. Nevertheless, estrogen modulation affected the levels of these proteins, suggesting that tamoxifen may have an important therapeutic role in ER-positive cancers expressing high levels of Cks1 or Skp2.

We found a strong correlation between young age of the patient and overexpression of either Cks1 or Skp2. Thus, these results support the notion that breast cancer has more aggressive tumor biology in young patients than in older ones, and that this difference may account, at least in part, for the poorer survival rates of younger patients than of older patients with similar clinicopathological features. Overall, Cks1 or Skp2 were each found to be good prognostic markers for disease-free and overall survival. Interestingly, there was no significant association between p27Kip1 expression and overall survival $(P=0.083)$. A possible reason for this finding is the relatively small number of patients in this study. Larger studies may be required to resolve this issue.

\section{Conclusion}

The results of the present study provide additional insights into the importance of alterations in cell-cycle regulatory proteins and tumor progression in breast cancer. Our findings suggest that Cks1 has an important role in the deregulation of the cellcycle protein $\mathrm{p} 27_{\mathrm{Kip} 1}$ in breast cancer. Overexpression of Cks1 was strongly associated with increased Skp2 expression and down regulation of $\mathrm{p} 27^{\mathrm{Kip} 1}$ levels, resulting in aggressive tumor behavior and poor prognosis. Thus, both $\mathrm{Cks} 1$ and Skp2 may be considered as potential novel prognostic markers and targets for the future development of specific therapeutic interventions in breast cancer.

\section{Competing interests}

The authors declare that they have no competing interests.

\section{Authors' contributions}

MS (Merav Slotky) and MS (Ma'anit Shapira) contributed equally in the preparation of the study. Both carried out the immunohistochemical studies and the immunobot analysis, participated in the sequence alignment, and drafted the manuscript. $\mathrm{OBI}$ carried out the pathological and immunohistochemical analysis and interpretation. SL and BF participated in the design of the study and performed the statistical analysis. MT collected and analyzed the clinical data and helped draft the manuscript. DDH conceived of the study, participated in its design and coordination, and helped to draft the manuscript. All authors read and approved the final manuscript.

\section{Acknowledgements}

We thank Dr Avram Hershko for critical review and Dr Micha Bar-Hanna and Mrs Miriam Alon from the Israel Cancer Registry for their assistance. This study was supported by the Israel Cancer Research Fund and the Israel ministry of Health.

\section{References}

1. Morabito A, Magnani E, Gion M, Sarmiento R, Capaccetti B, Longo $R$, Gattuso D, Gasparini G: Prognostic and predictive indicators in operable breast cancer. Clin Breast Cancer 2003, 3:381-390.

2. Tsihlias J, Kapusta L, Slingerland J: The prognostic significance of altered cyclin-dependent kinase inhibitors in human cancer. Annu Rev Med 1999, 50:401-423.

3. Alkarain A, Jordan R, Slingerland J: p27 deregulation in breast cancer: prognostic significance and implications for therapy. J Mammary Gland Biol Neoplasia 2004, 9:67-80.

4. Chiarle R, Pagano M, Inghirami G: The cyclin dependent kinase inhibitor p27 and its prognostic role in breast cancer. Breast Cancer Res 2001, 3:91-94. 
5. Catzavelos C, Bhattacharya N, Ung YC, Wilson JA, Roncari L, Sandhu C, Shaw P, Yeger H, Morava-Protzner I, Kapusta L, Franssen $\mathrm{E}$, et al:: Decreased levels of the cell-cycle inhibitor p27Kip1 protein: prognostic implications in primary breast cancer. Nat Med 1997, 3:227-230.

6. Loda M, Cukor B, Tam SW, Lavin P, Fiorentino M, Draetta GF, Jessup JM, Pagano M: Increased proteasome-dependent degradation of the cyclin-dependent kinase inhibitor p27 in aggressive colorectal carcinomas. Nat Med 1997, 3:231-234.

7. Tsihlias J, Kapusta LR, DeBoer G, Morava-Protzner I, Zbieranowski I, Bhattacharya N, Catzavelos GC, Klotz LH, Slingerland JM: Loss of cyclin-dependent kinase inhibitor p27Kip1 is a novel prognostic factor in localized human prostate adenocarcinoma. Cancer Res 1998, 58:542-548.

8. Hommura F, Dosaka-Akita H, Mishina T, Nishi M, Kojima T, Hiroumi $\mathrm{H}$, Ogura S, Shimizu M, Katoh H, Kawakami Y: Prognostic significance of p27KIP1 protein and ki-67 growth fraction in nonsmall cell lung cancers. Clin Cancer Res 2000, 6:4073-4081.

9. Pagano M, Tam SW, Theodoras AM, Beer-Romero P, Del Sal G, Chau V, Yew PR, Draetta GF, Rolfe M: Role of the ubiquitin-proteasome pathway in regulating abundance of the cyclindependent kinase inhibitor p27. Science 1995, 269:682-685.

10. Hershko A, Ciechanover A: The ubiquitin system. Annu Rev Biochem 1998, 67:425-479.

11. Carrano AC, Eytan E, Hershko A, Pagano M: SKP2 is required for ubiquitin-mediated degradation of the CDK inhibitor p27. Nat Cell Biol 1999, 1:193-199.

12. Sutterluty $H$, Chatelain $E$, Marti $A$, Wirbelauer $C$, Senften $M$, Muller $\mathrm{U}$, Krek W: p45SKP2 promotes p27Kip1 degradation and induces $\mathbf{S}$ phase in quiescent cells. Nat Cell Biol 1999, 1:207-214.

13. Tsvetkov LM, Yeh KH, Lee SJ, Sun $\mathrm{H}$, Zhang H: p27(Kip1) ubiquitination and degradation is regulated by the SCF(Skp2) complex through phosphorylated Thr187 in p27. Curr Biol 1999, 9:661-664.

14. Signoretti S, Di Marcotullio L, Richardson A, Ramaswamy S, Isaac $B$, Rue M, Monti F, Loda M, Pagano M: Oncogenic role of the ubiquitin ligase subunit Skp2 in human breast cancer. $J$ Clin Invest 2002, 110:633-641.

15. Hershko D, Bornstein G, Ben-Izhak O, Carrano A, Pagano M, Krausz MM, Hershko A: Inverse relation between levels of p27(Kip1) and of its ubiquitin ligase subunit Skp2 in colorectal carcinomas. Cancer 2001, 91:1745-1751.

16. Gstaiger M, Jordan R, Lim M, Catzavelos C, Mestan J, Slingerland J, Krek W: Skp2 is oncogenic and overexpressed in human cancers. Proc Natl Acad Sci USA 2001, 98:5043-5048.

17. Yang G, Ayala G, De Marzo A, Tian W, Frolov A, Wheeler TM, Thompson TC, Harper JW: Elevated Skp2 protein expression in human prostate cancer: association with loss of the cyclindependent kinase inhibitor p27 and PTEN and with reduced recurrence-free survival. Clin Cancer Res 2002, 8:3419-3426.

18. Ganoth D, Bornstein G, Ko TK, Larsen B, Tyers M, Pagano M, Hershko A: The cell-cycle regulatory protein Cks1 is required for SCF(Skp2)-mediated ubiquitinylation of p27. Nat Cell Biol 2001, 3:321-324.

19. Spruck C, Strohmaier H, Watson M, Smith AP, Ryan A, Krek TW, Reed SI: A CDK-independent function of mammalian Cks1: targeting of SCF(Skp2) to the CDK inhibitor p27Kip1. Mol Cell 2001, 7:639-650.

20. Masuda TA, Inoue H, Nishida K, Sonoda H, Yoshikawa Y, Kakeji Y, Utsunomiya T, Mori M: Cyclin-dependent kinase 1 gene expression is associated with poor prognosis in gastric carcinoma. Clin Cancer Res 2003, 9:5693-5698.

21. Inui N, Kitagawa K, Miwa S, Hattori T, Chida K, Nakamura H, Kitagawa $\mathrm{M}$ : High expression of $\mathrm{Cks} 1$ in human non-small cell lung carcinomas. Biochem Biophys Res Commun 2003, 303:978-984

22. Kitajima S, Kudo Y, Ogawa I, Bashir T, Kitagawa M, Miyauchi M, Pagano M, Takata T: Role of Cks1 overexpression in oral squamous cell carcinomas: cooperation with Skp2 in promoting p27 degradation. Am J Pathol 2004, 165:2147-2155.

23. Shapira M, Ben-Izhak O, Bishara B, Futerman B, Minkov I, Krausz MM, Pagano M, Hershko DD: Alterations in the expression of the cell cycle regulatory protein cyclin kinase subunit 1 in colorectal carcinoma. Cancer 2004, 100:1615-1621.

24. Shapira M, Ben-lzhak O, Linn S, Futerman B, Minkov I, Hershko DD: The prognostic impact of the ubiquitin ligase subunits
Skp2 and Cks1 in colorectal carcinoma. Cancer 2005, 103:1336-1346. 